\section{Estimating the mechanical stability of Pinus nigra Arn. using an alternative approach across several plantations in central Italy}

\author{
Paolo Cantiani, Ugo Chiavetta
}

Black pine has been used often in central and southern Italy to reforest mountainous areas depleted by the intensive use of natural resources. The main purpose of establishing pine forests in Italy was to protect the soil from excessive erosion, and also to facilitate the natural succession toward mixed forests with deciduous species. The most common silvicultural treatments in Europe currently aim at maximizing the stability of the stands and facilitating the transition from pure to mixed stands comprising a larger component of native tree species. In this work, we investigated the relationships between the living whorls number and four indexes of individual tree stability: the slenderness ratio, the crown depth, the crown projection, and an eccentricity index of the canopy. The data set used was composed of 1098 trees from ten black pine plantations located in central Italy. Our results demonstrate that the living whorls number can be handily used to predict the slenderness ratio with an error of $18 \%$. A non-parametric model based on a reduced number of field measures was obtained as a support for thinning operations aimed at improving single tree stability.

Keywords: Black Pine, Tree Stability, Living Whorl Number, Slenderness Ratio, Crown Depth, Crown Projection, Crown Eccentricity

\section{Introduction \\ In Central Europe, the Balkans, and Me- diterranean countries black pine (Pinus ni- gra Arn.) is commonly planted for protec- tion purposes (Bussotti 2002). In Italy, this practice was established at the national level in the $20^{\text {th }}$ century in accordance with a po- licy that was developed to protect the land from erosion (Piermattei et al. 2012). \\ Black pine has been used often in central and southern Italy to reforest mountainous areas depleted by the intensive use of natural resources, especially during World War I and II. Toward the end of the 1970s, the mandatory requirement to reforest these areas using coniferous species was disconti- nued. In Italy, black pine occurs mostly in pure stands of even-aged forests (50 years old on average) and covers an area of 236467 hectares (Gasparini \& Tabacchi 2011).}

Black pine has been used widely across

Italy because of its typical characteristics of a pioneer species: low mortality, rapid juvenile growth, low incidence of health issues, and the ability to improve both chemical and physical characteristics of the soil. Among the sub-species of Pinus nigra Arn., the European black pine (Pinus nigra Arn. subsp. nigra) was used more commonly on calcareous soils and Pinus nigra subsp. laricio Maire was preferred on sandstone soils. The main purpose of establishing pine forests in Italy was to protect the soil from erosion, and also to facilitate the natural succession toward mixed forests with a strong component of deciduous species (Cantiani et al. 2010). The commercial value of these pine forests was not a priority.

The most common silvicultural treatments in Europe currently aim at maximizing the stability and facilitating the transition from pure stands to mixed stands with a stronger component of native tree species (Mosandl

$\square$ Consiglio per la Ricerca in Agricoltura e l'Analisi dell'Economia Agraria, Forestry Research Center, v.le Santa Margherita 80, I-52100 Arezzo (Italy)

(a) Ugo Chiavetta (ugo.chiavetta@entecra.it)

Received: Mar 26, 2014 - Accepted: Oct 18, 2014

Citation: Cantiani P, Chiavetta U, 2015. Estimating the mechanical stability of Pinus nigra Arn. using an alternative approach across several plantations in central Italy. iForest 8: 846852 [online 2015-04-08] URL: http://www.sisef.it/iforest/contents/?id=ifor1300-007

Communicated by: Chris Eastaugh
\& Kessner 1999, Heitz \& Hasenauer 2000, Kenk \& Guehne 2001, Malcolm et al. 2001, Kint et al. 2006). Black pine was usually planted in pure stands at a density of 2500 trees per hectare with a rotation period of approximately 90 years depending on the site characteristics. During the rotation period multiple thinning usually should be applied to facilitate the transition toward a mixed forest. The average stand age of Italian pine forest is 50 years; consequently, there is still a need for additional research to understand the most effective treatments required to convert these pure pine forests.

On privately owned forests (approximately $47 \%$ of the total), the most common treatment is a clear cut on small patches followed by artificial regeneration of native species (e.g., Acer pseudoplatanus L., Acer opalus Mill., Quercus cerris L., Fraxinus ornus L., etc.). On public land, larger areas are commonly harvested (e.g., strips, patches) in order to facilitate the natural regeneration of native species.

Thinning is the most effective silvicultural treatment to enhance the ecological value of these stands. Pure pine stands reach canopy closure at an early age; therefore, it is important to conduct pre-commercial thinning at about age 30 followed by additional thinning every 15 years (Cameron 2002, Brüchert \& Gardiner 2006). However, multiple thinning is costly and in Italy the necessary treatments have not been applied regularly. In these forests, the most common treatment is thinning from below, which removes only those trees below the main canopy layer that show phytosanitary issues or diseased stems. This trees are mainly dominated.

Cantiani et al. (2010) indicated that black pine can still benefit from late thinning (at the age of 45), thus quickly reaching crown closure when treatments are carried out on the dominant layer. This operation can cause an initial disruption in the crown coverage. Consequently, it is important to evaluate the vigor of the crown and the social status of each tree before proceeding with a silvicultural treatment similar to thinning from above.

Moreover, tree susceptibility to wind and snow damage depends on many physical and ecological factors including: (1) soil characteristics, slope and climate (Copeland et al. 1996, Moore 2000, Quine 2000, Talkkari et al. 2000, Cucchi \& Bert 2003, Zeng et al. 2010); (2) species composition, density, diameter distribution, and vertical structure (Valinger et al. 1993, Quine 1995); and (3) the morphological and structural characteristics of individual plants (Coutts 1983, Petty \& Swain 1985, Gardiner et al. 1997, Mitchell 2000, Wilson \& Oliver 2000, Nicoll et al. 2006, Peltola 2006). The first factor is not influenced by management and cannot be 
Tab. 1 - Plot location and other key information about the pine stands surveyed for this study.

\begin{tabular}{|c|c|c|c|c|c|c|c|c|}
\hline Site & $\begin{array}{l}\text { Site } \\
\text { code }\end{array}$ & $\begin{array}{l}\text { Elevation } \\
\text { (m a.s.l.) }\end{array}$ & Aspect & $\begin{array}{l}\text { Stand age } \\
\text { (years) }\end{array}$ & $\begin{array}{l}\text { Tree density } \\
\left(\text { trees ha }^{-1}\right)\end{array}$ & $\begin{array}{c}\text { Basal area } \\
\left(\mathbf{m}^{2} \mathbf{h a}^{-1}\right)\end{array}$ & $\begin{array}{c}\text { Quadratic } \\
\text { mean DBH }(\mathbf{c m})\end{array}$ & $\begin{array}{c}\text { Stand mean } \\
\text { height }(\mathrm{m})\end{array}$ \\
\hline Monte Amiata & $\mathrm{AM}$ & 930 & $\mathrm{NE}$ & 40 & 998 & 48.3 & 24.3 & 22.3 \\
\hline Fonte Archese & AR & 750 & SW & 33 & 1342 & 66.75 & 22.7 & 15.65 \\
\hline La Baita & BA & 880 & SW & 51 & 1216 & 88.6 & 30.5 & 20.4 \\
\hline Fonte dei Frassini & FR & 1020 & $\mathrm{~W}$ & 35 & 1286 & 61.2 & 24.75 & 15.55 \\
\hline Monte Modina & $\mathrm{MO}$ & 1050 & SE & 80 & 956.5 & 60 & 26.7 & 20.6 \\
\hline Palmoline & PA & 1000 & $\mathrm{NE}$ & 55 & 946.5 & 61.8 & 29.45 & 21.6 \\
\hline Pigelleto & PG & 765 & NW & 67 & 510 & 35.5 & 34.8 & 24.3 \\
\hline Fonte del Pesce & PS & 1210 & W & 50 & 896.5 & 73.35 & 33 & 19.8 \\
\hline Monte Pettenaio & PT & 1000 & NW & 35 & 1377 & 35.35 & 18.75 & 13.05 \\
\hline Lo Scoiattolo & $\mathrm{SC}$ & 900 & $\mathrm{~W}$ & 57 & 1048 & 61.34 & 27 & 23.7 \\
\hline
\end{tabular}

controlled by foresters, the second factor can be controlled only in the long term, the third factor can be very useful in short-term management planning. Indeed, structural characteristics of trees can be a selection criterion on which to base thinning. In the literature, many indicators were used to assess tree stability by morphological and structural characteristics at tree level. The most frequently used indicators are: (a) the height/DBH ratio (slenderness coefficient or taper); (b) the relative depth of the crown; (c) the crown projection; and (d) the crown eccentricity.

The main goal of this study was to investigate a simple and non-invasive method suitable to assess the vigor and vertical stability of pine trees by counting the living whorls along the stem. We also wanted to evaluate whether such method could be particularly effective when selecting the trees that will be preserved from thinning (selective thinning approach)

\section{Materials and methods}

\section{Sample description}

The target population in this study was represented by all experimental plots held by the Italian Forestry Research Center (CRASEL) on black pine plantations in central Italy.

The data set used for this work was composed of 1098 trees. The trees were selected randomly from the CRA-SEL database of experimental black pine plots. The main descriptive parameters of these stands are reported in Tab. 1.

All the stands analyzed were located in central Italy (Fig. 1). With the exception of the MO site, these forests were established on public land since the middle of the past century. The majority of black pine reforestation occurs in central Apennines; consequently, the stands our data come from have an average age of 50 years.

The average density was approximately 2500 trees per hectare following common es-

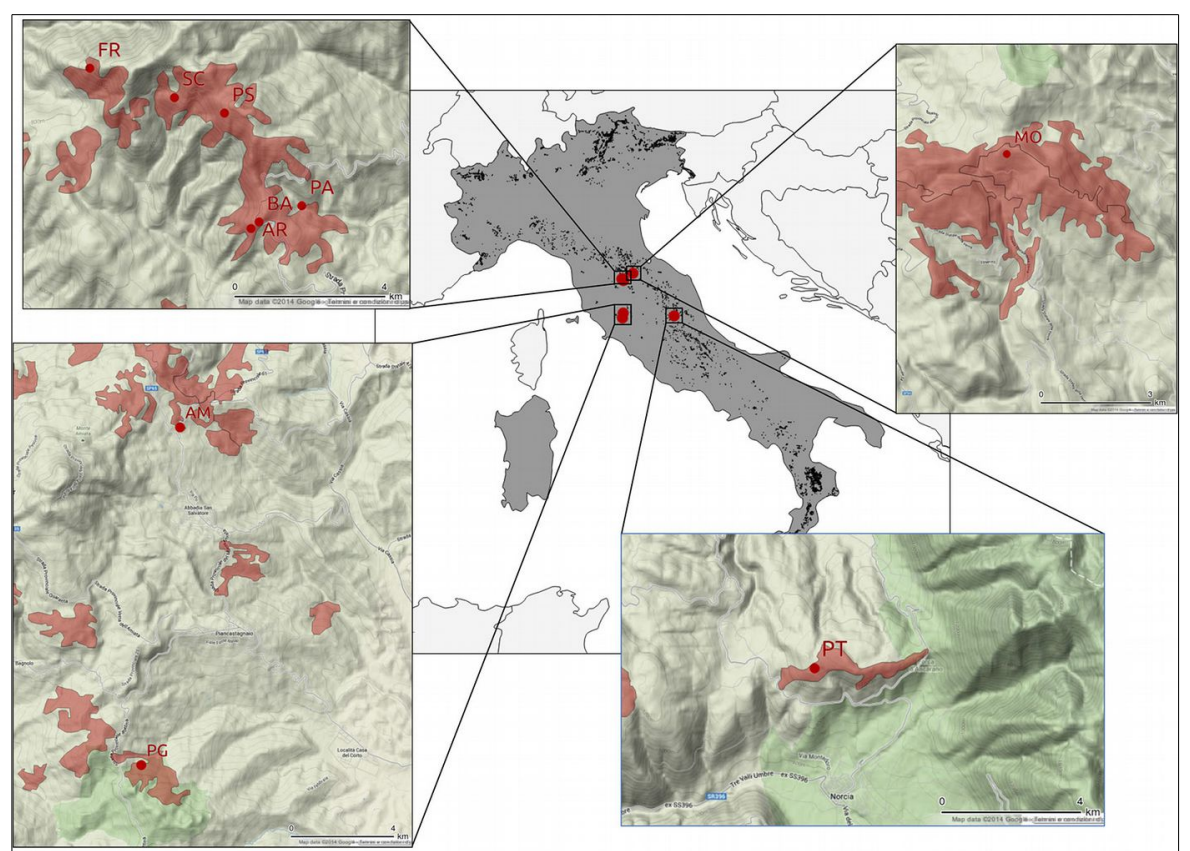

Fig. 1 - Study sites location (red dots) relative to the distribution of black pine stands in Italy (black/red areas). tablishment treatments. Pre-commercial thinning was not applied. No thinning had been carried out at the time of the survey at the following locations: AR, FR, PT, and SC; at the other locations, a light thinning from below was applied. At the time of the survey, stands presented crown closure with ongoing intra-specific competition.

Tab. 2 provides information on the stands from which the trees were selected, such as number of trees, average diameter at $1.3 \mathrm{~m}$ height (DBH), DBH range, average height, and height range. The 1098 sampled trees were classified in three social classes: (a) dominant trees (classes 1 and 2 of Kraft Pretzsch 2010); (b) co-dominant trees (class 3 of Kraft); and (c) subdominant trees (class 4 and 5 of Kraft).

The sample trees were selected randomly from each stand. A total of 329 dominant trees, 371 co-dominant trees, and 398 subdominant trees were used for the statistical analysis.

\section{Measures and variables}

The tree-level measurements used for the models were: (a) diameter at $1.30 \mathrm{~m}$ height (DBH); (b) total height (Ht); (c) height of first living whorl (Hc); (d) projection on the ground of 4 orthogonal crown radii (i.e., North, East, South and West - Rc); and (e) number of living whorls from the top of the crown to the lowest living whorl (LWN).

Five variables, relative to the overall stability of the tree, were selected and included: (a) the number of living whorls (LWN); (b) the height/DBH ratio (slenderness coefficient or taper-HD); (c) the relative depth of the crown (CD); (d) the crown projection (CP); (e) the crown eccentricity (largest radius / smallest radius - EC, Brüchert \& Gardiner 2006 - Tab. 3).

\section{Exploratory analysis}

A principal component analysis (PCA) and a non-parametric correlation analysis (NPC) were used to investigate the relationship between the stability indexes (e.g., LWN, HD, $\mathrm{CD})$, and the significant variables were modeled using the Local Weighted Scatterplot 
Smoothing (LOWESS or LOESS - Cleveland 1978, 1981, Cleveland \& Devlin 1988).

PCA was used to detect the predictability of the five variables (i.e., $\mathrm{LWN}, \mathrm{HD}, \mathrm{CD}$, $\mathrm{CE}, \mathrm{CP})$. The function PRINCOMP $\{$ STATS $\} \mathrm{im}-$ plemented in the $\mathrm{R}$ environment ( $\mathrm{R}$ Core Team 2013) was applied on the correlation matrix.

The Shapiro-Wilk test (Shapiro \& Wilk 1965) was used to investigate whether the selected variables were normally distributed (Tab. 4). Significant departures from normality were observed for most variables, as well as for their logarithmic and root square transformation, and therefore a non-parametric statistical analysis was applied. For this reason, the Spearman's correlation coefficients ( $\rho$ - Spearman 1904) were calculated to investigate the relationships between the stability indexes and LWN using the function RCORR $\{$ HMISC $\}$ of the R software (Harrell 2012, R Core Team 2013). Furthermore, the use of a non-parametric test allowed the detection of non-linear relationships among variables.

Crown development is influenced by light availability and by the location of each crown in relation to the surrounding trees. For this reason, the correlation test was performed on the whole dataset and by social class. We used a threshold p-level of 0.001 to determine the significance of the correlation coefficients, also considering the Bonferroni's correction (Dunn 1961).

\section{Modeling}

The relationship between $\mathrm{HD}$ and LWN was modeled using a non-parametric analysis for two reasons: (a) most variables were not normally distributed (Tab. 4) even after logarithmic or square root transformation; (b) LWN is a discrete variable. Moreover, a parametric approach would be not robust because the relationship between the variables was unknown. A Locally Weighted Scatterplot Smoothing regression (LOWESS) was used to this purpose (Cleveland 1978, 1981, Cleveland \& Devlin 1988). The LOEsS \{STATS function implemented in the R software (R Core Team 2013) was used to build the model. The portion of the dataset for local smoothing was $\alpha=0.6$ with a weight $W_{\mathrm{i}}$ for each decreasing value, as a function of the distance according to the following equation (eqn. 1):

$$
W_{i}=\left[1-\left(\frac{D_{i}}{\text { maxDist }}\right)^{3}\right]^{3}
$$

where $D_{\mathrm{i}}$ is the distance of the $i$-th observed value in the $\alpha$ interval; $\max D$ is the distance of the farthest observed point in the $\alpha$ interval.

To set the $\alpha$ level we performed several attempts, thereby the $\alpha$ level was arbitrarily set at 0.6 under two considerations: (a) lower $\alpha$

Tab. 2 - Descriptive statistics of the sample trees used for this study.

\begin{tabular}{lccccc}
\hline Site code & $\begin{array}{c}\text { Number of } \\
\text { sample trees }\end{array}$ & $\begin{array}{c}\text { Mean DBH } \\
(\mathbf{c m})\end{array}$ & $\begin{array}{c}\text { DBH range } \\
(\mathbf{c m})\end{array}$ & $\begin{array}{c}\text { Mean height } \\
(\mathbf{m})\end{array}$ & $\begin{array}{c}\text { Height range } \\
(\mathbf{m})\end{array}$ \\
\hline AM & 70 & 23.6 & $14-42$ & 22.3 & $18.1-27.5$ \\
AR & 85 & 22.9 & $13-34$ & 13.6 & $10.4-19.1$ \\
BA & 226 & 27.5 & $15-56$ & 19.4 & $11.4-27.4$ \\
FR & 59 & 30.3 & $18-46$ & 19.2 & $14.9-21.8$ \\
MO & 137 & 28.7 & $13-51$ & 21.3 & $15.6-27.7$ \\
PA & 135 & 28.3 & $16-50$ & 21.4 & $12.2-26.5$ \\
PG & 20 & 33.6 & $26-43$ & 24.5 & $21.3-26.8$ \\
PS & 102 & 23.2 & $10-38$ & 15.2 & $10.1-18.8$ \\
PT & 130 & 18.4 & $9-30$ & 14.7 & $7.3-19.6$ \\
SC & 134 & 24.8 & $13-46$ & 20.7 & $14.3-29.0$ \\
Total & 1098 & 25.6 & $9-56$ & 18.9 & $7.3-29.0$ \\
\hline
\end{tabular}

Tab. 3 - Descriptive statistics for the following variables: the living whorls number (LWN); the slenderness ratio (HD), the crown depth (CD), the crown projection area (CP) and an eccentricity index of the canopy (EC). (Ht): total height $(\mathrm{m})$; (DBH): diameter at $1.3 \mathrm{~m}$ height $(\mathrm{m})$; (Hc): height of first living whorl (m); (Rcmean); arithmetic mean of the crown projection radii (m); (Rcmax): greater of the crown projection radii (m); (Rcmin): smallest of the crown projection radii $(\mathrm{m}) ;(\mathrm{CV})$ : coefficient of variation.

\begin{tabular}{|c|c|c|c|c|c|c|c|}
\hline Variable & Dimension & Formula & Min & Mean & Median & Max & $\mathrm{CV}$ \\
\hline LWN & count & - & 1 & 16.73 & 16 & 39 & 0.39 \\
\hline HD & adimensional & $\mathrm{Ht} / \mathrm{DBH}$ & 36.07 & 77.52 & 75 & 148.57 & 0.24 \\
\hline CD & adimensional & 1-(Hc/Ht) & 0.6289 & 35.3891 & 35.4052 & 60.4545 & 0.26 \\
\hline $\mathrm{CP}$ & $\mathrm{m}^{2}$ & $\pi$ Rcmean $^{2}$ & 0.00014 & 0.379 & 0.36364 & 1 & 0.58 \\
\hline $\mathrm{CE}$ & adimensional & Rcmax/Rcmin & 0.126 & 12.788 & 8.042 & 128.648 & 1.19 \\
\hline
\end{tabular}

levels would introduce undulations in the model due to the local distribution of the data; (b) higher $\alpha$ levels would progressively transform the model towards a linear model.

The local regression was performed by the method of weighted least squares. The analytical form of this non-parametric model was provided by the LOWESS algorithm and applied to data by using an ad-hoc script in R language (Cleveland 1978, 1981, Cleveland \& Devlin 1988, R Core Team 2013). The model was validated by the leave-oneout cross validation using the function ERROREST $\{$ IPRED $\}$ of the R software (Peters \& Hothorn 2009, R Core Team 2013). One observation for each of the 1098 model itera-

Tab. 4 - Results of Shapiro-Wilk normality test (Shapiro \& Wilk 1965).

\begin{tabular}{|c|c|c|c|}
\hline Variable Name & Length & $\mathbf{W}$ & p-value \\
\hline LWN & 1098 & 0.9725 & 0.00000 \\
\hline $\mathrm{CD}$ & 1098 & 0.9974 & 0.07112 \\
\hline $\mathrm{HD}$ & 1098 & 0.9622 & 0.00000 \\
\hline $\mathrm{CE}$ & 1028 & 0.9793 & 0.00000 \\
\hline $\mathrm{CP}$ & 1028 & 0.6896 & 0.00000 \\
\hline $\log (\mathrm{LWN})$ & 1098 & 0.9737 & 0.00000 \\
\hline $\log (\mathrm{CD})$ & 1098 & 0.9966 & 0.01689 \\
\hline $\log (\mathrm{HD})$ & 1098 & 0.8075 & 0.00000 \\
\hline $\log (\mathrm{CE})$ & 1028 & 0.5811 & 0.00000 \\
\hline $\log (\mathrm{CP})$ & 1028 & 0.9869 & 0.00000 \\
\hline $\mathrm{LWN}^{1 / 2}$ & 1098 & 0.9948 & 0.00076 \\
\hline $\mathrm{CD}^{1 / 2}$ & 1098 & 0.9849 & 0.00000 \\
\hline $\mathrm{HD}^{1 / 2}$ & 1098 & 0.9714 & 0.00000 \\
\hline $\mathrm{CE}^{1 / 2}$ & 1028 & 0.9466 & 0.00000 \\
\hline $\mathrm{CP}^{1 / 2}$ & 1028 & 0.9130 & 0.00000 \\
\hline
\end{tabular}

tions carried out was excluded from the training dataset. Then, the value estimated by the model was compared for each run with the observed value. In this way, the mean square error (RMSE) and the mean square error percentage $(\%$ RMSE) were determined.

\section{Results}

Significant departures from the normal distribution were observed using the ShapiroWilk test for almost all variables and their most common transformations (Tab. 4).

A good correlation both for LWN-CD and LWN-HD was found using the Spearman test (Tab. 5) both for the whole dataset $(|\rho|>$ 
Tab. 5 - Results of non-parametric correlation tests (Spearman 1904) between LWN and the other variables with and without stratification by social classes.

\begin{tabular}{llcccc}
\hline Stratum & Statistics & CD & HD & EC & CP \\
\hline All social & $\rho$ & 0.6648 & -0.6263 & -0.2729 & 0.4770 \\
classes & p-value & 0.00000 & 0.00000 & 0.00000 & 0.00000 \\
& Observations & 1098 & 1098 & 1028 & 1028 \\
\hline Dominant & $\rho$ & 0.5357 & -0.3312 & -0.2055 & -0.0981 \\
trees & $\mathrm{p}$-value & 0.00000 & 0.00000 & 0.00026 & 0.08351 \\
& Observations & 329 & 329 & 312 & 312 \\
\hline Co-dominant & $\rho$ & 0.6032 & -0.5226 & -0.1733 & 0.3314 \\
trees & p-value & 0.00000 & 0.00000 & 0.00099 & 0.00000 \\
& Observations & 371 & 371 & 358 & 358 \\
\hline Sub-dominant & $\rho$ & 0.5679 & -0.4763 & -0.0711 & 0.3692 \\
trees & p-value & 0.00000 & 0.00000 & 0.17932 & 0.00000 \\
& Observations & 398 & 398 & 358 & 358 \\
\hline
\end{tabular}

$0.6)$ and for all the strata according to the various social classes $(|\rho|>0.45)$, except for the dominant layer $(\rho=0.33)$. In both cases, a positive correlation was found between LWN and CD, while a negative correlation was detected between LWN and HD. Furthermore, the correlation coefficient was always highly significant $(\mathrm{p}<0.00001)$. Contrastingly, the correlation between LWN and $\mathrm{CE}$ was always poor when using either the entire dataset or the social classes $(|\rho|<0.3)$. The correlation ceofficient was negative and highly significant ( $\mathrm{p}$-value $<0.001)$. The correlation between LWN and CP was equal to $|\rho|=0.48$ when using the whole dataset and decreased to $|\rho|<0.3$ when the sample

was stratified by social class. The correlation was always positive and highly significant (p-value $<0.0001$ ), with the exception of dominant trees.

The PCA carried out showed a clear distinction between three groups of variables (Fig. 2). The first group was composed of $\mathrm{CP}, \mathrm{CD}$ and LWN, the second group was composed of HD and the third group was composed of CE. The first and the second group accounted for a similar amount of variance, but with opposite effect. The third group, instead, was perpendicular to the other two groups and explained an additional portion of the total variance.

The model obtained for the estimation of

Fig. 3 - Model calibration. Model for estimating the slenderness ratio $(\mathrm{HD}$, red line) based on the living whorls number (LWN).

Data used for model calibration are plotted $(\times)$.

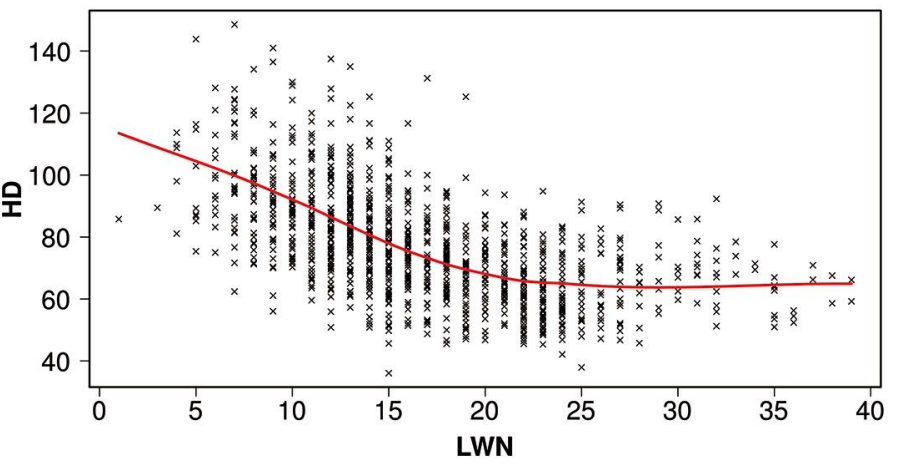

Fig. 4 - Graphical representation of the model obtained (blue line) and its RMSE (light blue area).

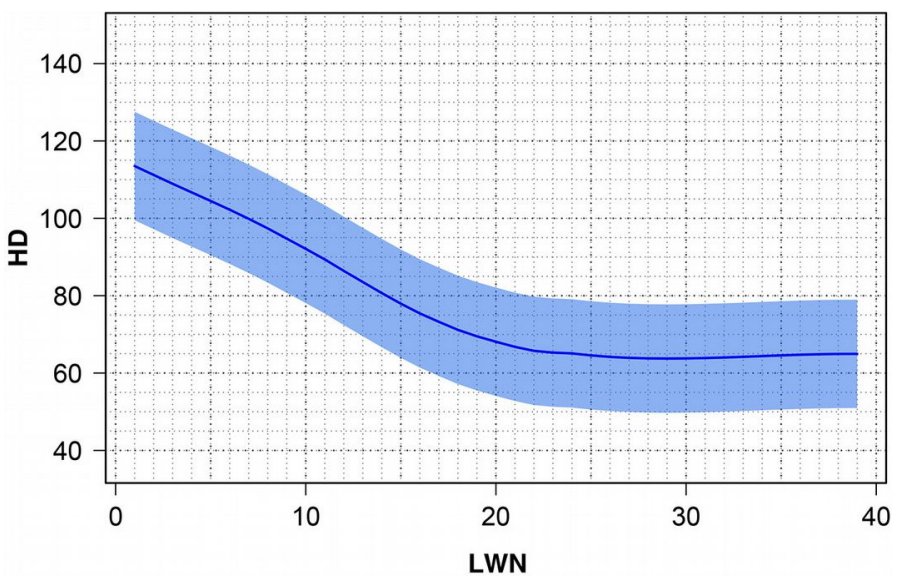

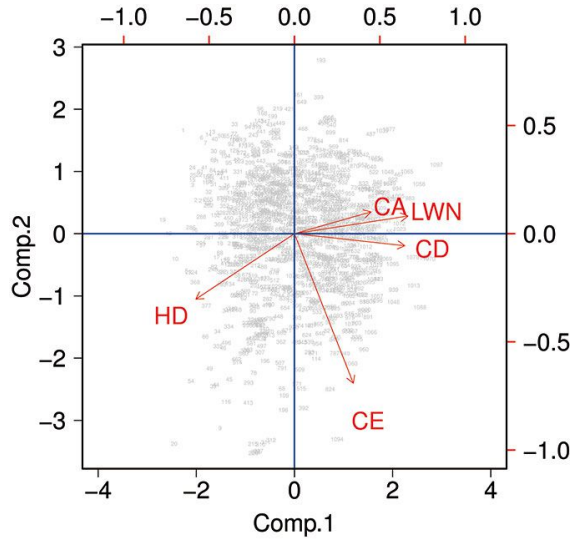

Fig. 2 - Biplot of the PCA.

the slenderness ratio (HD) based on the based on the living whorls number (LWN) is represented in a graphic form in Fig. 3 and Fig. 4. The leave-one-out cross validation of the local regression model resulted in an accuracy of $82 \%(\mathrm{RMSE}=14.34, \mathrm{RMSE} \%=$ $18 \%$ ).

The general form of the model obtained showed a decreasing trend of HD up to a value of $L W N=23$. Then, further increases of LWN values did not determine any further reduction of $\mathrm{HD}$.

\section{Discussion and conclusions}

The results of this study indicated a significant relationship between LWN and three out of the four selected stability indexes. As expected, the best correlation was recorded between $\mathrm{LWN}$ and $\mathrm{CD}$, indicating that the higher is the number of live whorls, the greater is the depth of the crown. This effect may vary according to the distance between whorls. Site fertility and growing conditions have a direct effect of the distance between whorls (Vanninen et al. 1996), thus site-specific models would increase the predictive ability of LWN.

A significant correlation was also found between LWN and HD. Unlike the previous variables, these two parameters derive from independent measures, which makes LWN a good proxy of the parameter HD. Furthermore, accurate thresholds of stability in terms of HD have been investigated, and therefore LWN may become a valid indicator of individual tree stability.

The relationship between LWN and CP was relatively weak, which is not unexpected. This outcome shows that other factors may affect crown projection. Indeed, crown projection depends strongly on tree density, which was relatively heterogeneous among sites in this study. However, models that include tree density were not a priority, considering that the main goal of the present work was to provide a simple and effective way to assess tree stability in the field.

The relationship between LWN and the ec- 
centricity of the crown was relatively weak though statistically significant. Moreover, modeling by social class did not improve the ability of predicting HD based on the selected variables. The PCA analysis also indicated that $\mathrm{HD}, \mathrm{LWN}, \mathrm{CD}$ and $\mathrm{CP}$ indexes were highly correlated. On one hand, this confirms that HD is a strong indicator of tree stability, as suggested by previous studies (Peltola et al. 2000, Wilson \& Oliver 2000, Bachofen \& Zingg 2001, Slodicak \& Novak 2006, Bianchi et al. 2010, Pretzsch 2010). On the other hand, it demonstrates that LWN and $\mathrm{CD}$ can be similarly used to explain the same variation of the parameter HD.

In the scientific literature no studies have been carried out specifically about the mechanical stability of the black pine. Instead, many studies have investigated tree stability of European conifers (Tab. 6), including spruce and fir (Picea spp., Abies alba Mill.) and Pinus Radiata D. Don. These studies have indicated that interspecific variability in the HD stability area is relatively low and varies between 75 and 115 (average value = 92.5) for all conifers species combined, while the range is between 85 and 115 (average value $=93.5$ ) for Pinus spp. Compared with other conifers, only larch (Larix decidua Mill.) had a higher tree stability than black pine (Bouchon 1987). Similar to other conifers, a so-called "HD stability area" is likely between 60 and 90. An HD value above 90 indicates that the pine trees may have stability issues.

In this study, LWN and HD were highly correlated and both showed a strong relationship with tree stability. For all these reasons, our study focused on the relationship between LWN and HD. Furthermore, we demonstrated that there is a constant increase in tree stability for values of LWN up to 23 , while for higher values tree stability does not improve even when the number of whorls per tree increases.

Our model provides valid estimates of tree stability for two reasons: (i) the relationship between HD and tree stability indicates a gradual transition around the threshold value from a stable to an unstable tree; (ii) the use of LWN to estimate tree stability indicated that trees can be considered relatively stable for values of LWN higher than 11, and become even more stable for LWN values above 16 . This value is conservative and includes the $18 \%$ of estimated error. From a forest management perspective, the use of the LWN threshold of 16 may help forest managers to easily select pine trees for thinning. As an example, $50 \%$ of trees in our dataset had an LWN value above 16 .

In Italy, thinning of black pine forests is usually carried out by selecting trees from below and by using a moderate thinning intensity. In central Italy, the number of trees that can be removed from a stand is re-

Tab. 6 - Reference threshold values of slenderness ratio for the mechanical stability of different conifers.

\begin{tabular}{|c|c|c|c|}
\hline Species & $\begin{array}{l}\text { Slender- } \\
\text { ness ratio }\end{array}$ & $\begin{array}{l}\text { Country of study and } \\
\text { additional notes }\end{array}$ & Reference \\
\hline Picea abies (L.) H. & 100 & Germany & Thomasius et al. (1986) \\
\hline \multirow[t]{5}{*}{ Karst } & 90 & $\begin{array}{l}\text { France - Only for plant } \\
\text { from } 20 \text { to } 30 \mathrm{~m} \text { of height }\end{array}$ & $\begin{array}{l}\text { Bequey \& Riou-Nivert } \\
\text { (1987) }\end{array}$ \\
\hline & 100 & Czech republic & Slodicak \& Novak (2006) \\
\hline & 100 & Scotland & Milne (1995) \\
\hline & 100 & Slovakia & Konôpka (1999) \\
\hline & 80 & Germany & Abetz (1987) \\
\hline Pseudotsuga menziesii & 75 & Netherlands & Faber \& Sissingh (1975) \\
\hline Mirb. (Franco) & $85-90$ & Italy & La Marca (2005) \\
\hline Abies alba Mill. & $85-90$ & Italy & La Marca (2005) \\
\hline \multirow[t]{4}{*}{ Pinus radiata D. Don. } & $90-100$ & $\begin{array}{l}\text { Australia - Only for the } \\
\text { largest } 200 \text { trees }^{-1} \mathrm{ha}^{-1}\end{array}$ & Cremer et al. (1982) \\
\hline & 90 & Galicia & Castedo-Dorado et al. (2009) \\
\hline & 85 & South Africa & $\begin{array}{l}\text { Von Gadow \& Bredenkamp } \\
\text { (1992) }\end{array}$ \\
\hline & 85 & South Africa & Hinze \& Wessels (2002) \\
\hline $\begin{array}{l}\text { Pinus patula } \text { Schiede } \\
\text { ex Schlechtendal et } \\
\text { Chamisso, } \\
\text { Pinus elliottii Engelm, } \\
\text { Pinus pinaster Aiton, } \\
\text { Pinus taeda } \text { L. }\end{array}$ & 115 & South Africa & Hinze \& Wessels (2002) \\
\hline Pinus sylvestris L. & 100 & Scotland & Petty \& Swain (1985) \\
\hline $\begin{array}{l}\text { Picea sitchensis } \\
\text { (Bong.) Carr. }\end{array}$ & 85 & United Kingdom & Hamilton \& Christie (1971) \\
\hline Various conifers & 100 & Canada & Wang et al. (1998) \\
\hline
\end{tabular}

stricted by law to $40 \%$ of the total. For this reason, thinning carried out on high-density stands may not be able to provide a beneficial effect to the overall stand dynamics, as the remaining trees quickly reach crown closure.

According to the most recent findings, thinning in Italian black pine-dominated forests should be more intense (Cantiani et al. 2010). The intensity of a thinning-frombelow approach should create gaps large enough to allow sufficient light penetration to the understory. Furthermore, we believe that other forest management practices, such as selective thinning, should be encouraged. Black pine is mainly used to reduce land degradation, and selective thinning should aim at maximizing tree health, so that the overall stability of the stand is improved. Released trees should be those more likely to thrive.

Our model provides a useful and easy-touse tool for selecting the most vigorous trees within a stand based on the number of whorls per tree. Due to the simplified procedure, using LWN to assess tree stability is less time consuming as compared with the use of HD. Indeed, the calculation of HD requires to measure two variables (DBH and $\mathrm{Ht}$ ), instead of a simple count of the living whorls. This relatively inexpensive method of estimating tree stability can be particularly important because Italian black pine forests have limited financial value, but high ecological and hydrological values.

An additional positive outcome of using LWN to assess tree stability is the easy and feasible quality control of thinning practices by competent authority even after the treatment. This method definitely could be used in operational applications in both private and public black pine stands. Furthermore, similar models also could be developed for other species whose whorls can be easily identified and counted.

\section{References}

Abetz P (1987). Why the crop tree aligned thinning system (ZB-Df) increases the stability and productivity of stands. In: Proceedings of the "Development of Thinning Systems to Reduce Stand Damages. IUFRO Group S1.05-05" (Knutell H ed). Department of Operational Efficiency, Faculty of Forestry, Swedish University of Agricultural Sciences, Garpenberg, Sweden, pp. 35-42.

Bachofen H, Zingg A (2001). Effectiveness of structure improvement thinning on stand structure in subalpine Norway spruce (Picea abies (L.) Karst.) stands. Forest Ecology and Management 145: 137-149. - doi: 10.1016/S0378-1127 (00)00581-8

Bequey J, Riou-Nivert P (1987). L'existence de "zones de stabilité" des peuplements. Conséquences sur la gestion [The existence of "stability zones" of the stands. Management implica- 
tions]. Revue Forestière Française 39 (4): 323 334. [in French] - doi: 10.4267/2042/25804

Bianchi L, Paci M, Bresciani A (2010). Effects of thinning intensities in experimental plots of Black European pine in "Foreste Casentinesi, Monte Falterona and Campigna National Park" (Tosco-Romagnolo Apennine, Italy), eight years after the felling. Forest@ - Journal of Silviculture and Forest Ecology (2): 73-83. [in Italian with English summary] - doi: 10.3832/efor0616007

Bouchon J (1987). Etat de la recherche relative aux dég'ts forestiers dus aux tempêtes [State of the art of research on forest damage caused by storms]. Revue Forestière Française 39 (4): 301312. [in French] - doi: $10.4267 / 2042 / 25802$

Brüchert F, Gardiner B (2006). The effect of wind exposure on the tree aerial architecture and biomechanics of Sitka spruce (Picea sitchensis, Pinaceae). American Journal of Botany 93 (10): 1512-21. - doi: 10.3732/ajb.93.10.1512

Bussotti F (2002). Pinus nigra Arnold. In: "Pines of Silvicultural Importance". CABI Publishing, Wallingford, UK, pp. 266-286.

Cameron AD (2002). Importance of early selective thinning in the development of long-term stand stability and improved log quality: a review. Forestry 75 (1): 25-35. - doi: 10.1093/forestry/75 .1 .25

Cantiani P, Plutino M, Amorini E (2010). Effects of silvicultural treatment on the stability of black pine plantations. Annals of Silvicultural Research 36: 49-58. - doi: 10.12899/asr-819

Castedo-Dorado F, Crecente-Campo F, AlvarezAlvarez P, Barrio-Anta M (2009). Development of a stand density management diagram for radiata pine stands including assessment of stand stability. Forestry 82 (1): 1-16. - doi: 10.1093/ forestry/cpm032

Cleveland WS (1978). Robust locally weighted regression and smoothing scatterplots. Journal of the American Statistical Association 74 (368): 829-836. - doi: 10.1080/01621459.1979.104810 38

Cleveland WS (1981). LOWESS: a program for smoothing scatterplots by robust locally weighted regression. American Statistician 35 (1): 54.

Cleveland WS, Devlin SJ (1988). Locally weighted regression: an approach to regression analysis by local fitting. Journal of the American Statistical Association 83 (403): 596-610. URL. doi: 10.1080/01621459.1988.10478639

Copeland JH, Pielke RA, Kittel TGF (1996). Potential climatic impacts of vegetation change: a regional modeling study. Journal of Geophysical Research 101 (D3): 7409. - doi: 10.1029/95JD 02676

Coutts MP (1983). Root architecture and tree stability. Plant and Soil 71 (1-3): 171-188. - doi: 10.1007/BF02182653

Cremer K, Borough C, McKinnell F, Carter P (1982). Effects of stocking and thinning on wind damage in [pine] plantations. New Zealand Journal of Forestry Science 12: 244-268. [online] URL: http://agris.fao.org/agris-search/search.do? recordID=NZ19830951058
Cucchi V, Bert D (2003). Wind-firmness in Pinus pinaster Ait. stands in southwest France: influence of stand density, fertilisation and breeding in two experimental stands damaged during the 1999 storm. Annals of Forest Science 60 (3): 209-226. - doi: 10.1051/forest:2003013

Dunn OJ (1961). Multiple comparisons among means. Journal of the American Statistical Association 56 (293): 52-64. URL. - doi: 10.1080/ 01621459.1961.10482090

Faber PJ, Sissingh G (1975). Stability of stands to wind. I. A theoretical approach. II. The practical viewpoint. Nederlands Bosbouwtijdschrift 47 (78): 179-193.

Gardiner BA, Stacey GR, Belcher RE, Wood CJ (1997). Field and wind tunnel assessments of the implications of respacing and thinning for tree stability. Forestry 70 (3): 233-252. - doi: 10.109 3/forestry/70.3.233

Gasparini P, Tabacchi G (2011). L'Inventario Nazionale delle Foreste e dei serbatoi forestali di Carbonio INFC 2005. Secondo inventario forestale nazionale italiano. Metodi e risultati [National Forest and Carbon sink Inventory INFC 2005. Second Italian national forest inventory. Methods and results]. Ministero delle Politiche Agricole, Alimentari e Forestali, Corpo Forestale dello Stato, Consiglio per la Ricerca e la Sperimentazione in Agricoltura, Unità di ricerca per il Monitoraggio e la Pianificazione Forestale, Edagricole-Il Sole 24 ore, Bologna, Italy, pp. 653. [in Italian]

Hamilton GJ, Christie JM (1971). Forest management tables (metric). Forestry Commission Booklet 34, HM Stationery Office, London, UK, pp. 201.

Harrell FE (2012). Hmisc: Harrell Miscellaneous. R package version 3.9-3, web site. [online] URL: http://cran.r-project.org/web/packages/Hmisc/index.html

Heitz R, Hasenauer H (2000). Reconversion of Norway spruce (Picea abies (L. ) Karst. ) stands into mixed forests: effects on soil properties and nutrient fluxes. In: Proceedings of the International Conference "Forest ecosystem restoration: ecological and economical impacts of restoration processes in secondary coniferous forests". Vienna (Austria) 10-12 Apr 2000. Institute of Forest Growth Research, Vienna, Austria, pp. 119125. [online] URL: http://www.cabdirect.org/ab stracts/20023 061095.html

Hinze WHF, Wessels NO (2002). Stand stability in pines: an important silvicultural criterion for the evaluation of thinnings and the development of thinning regimes. The Southern African Forestry Journal 196 (1): 37-40. - doi: 10.1080/ 20702620.2002.10434616

Kenk G, Guehne S (2001). Management of transformation in central Europe. Forest Ecology and Management 151 (1-3): 107-119. - doi: 10.1016/ S0378-1127(00)00701-5

Kint V, Geudens G, Mohren GMJ, Lust N (2006). Silvicultural interpretation of natural vegetation dynamics in ageing Scots pine stands for their conversion into mixed broadleaved stands. Forest Ecology and Management 223 (1-3): 363-
370. - doi: 10.1016/j.foreco.2005.11.018 Konôpka J (1999). Ohrozenie lesných porastov mechanicky pôsobiacimi abiotickými činitelmi [Abiotic factors threatening the mechanical stability of forest stands]. Lesnícky časopis (Forestry Journal) 45: 51-72. [in Slovak]

La Marca O (2005). Studi e ricerche sui danni da neve e vento nella foresta di Vallombrosa [Studies and researches on wind and snow damages in the forest of Vallombrosa]. L'Italia Forestale e Montana 60 (2): 193-202. [in Italian] [online] URL: http://agris.fao.org/agris-search/search.do? recordID $=$ IT2006602473

Malcolm DC, Mason WL, Clarke GC (2001). The transformation of conifer forests in Britain - regeneration, gap size and silvicultural systems. Forest Ecology and Management 151 (1-3): 723. - doi: 10.1016/S0378-1127(00)00692-7

Milne R (1995). Modelling mechanical stresses in living Sitka spruce stems. In: "Wind and Trees" (Coutts MP, Grace J eds). Cambridge University Press, Cambridge, UK, pp. 165-181. - doi: 10.1017/CBO9780511600425

Mitchell SJ (2000). Stem growth responses in Douglas-fir and Sitka spruce following thinning: implications for assessing wind-firmness. Forest Ecology and Management 135 (1-3): 105-114. doi: 10.1016/S0378-1127(00)00302-9

Moore JR (2000). Differences in maximum resistive bending moments of Pinus radiata trees grown on a range of soil types. Forest Ecology and Management 135 (1-3): 63-71. - doi: 10.1016/S0378-1127(00)00298-X

Mosandl R, Kessner R (1999). Conversion of pure pine and spruce forests into mixed forests in eastern Germany: some aspects of silvicultural strategy. In: "Management of Mixed-Species Forests: Silviculture and Economics (vol. 15)" (Olsthoorn AFM, Bartelink HH, Gardiner JJ, Pretzsch H, Hekhuis HJ, Franc A eds). IBN Scientific Contributions, Wageningen, The Netherlands, pp. 208-218.

Nicoll BC, Gardiner BA, Rayner B, Peace AJ (2006). Anchorage of coniferous trees in relation to species, soil type, and rooting depth. Canadian Journal of Forest Research 36 (7): 1871-1883. doi: 10.1139/x06-072

Peltola H (2006). Mechanical stability of trees under static loads. American journal of botany 93 (10): 1501-1511. - doi: 10.3732/ajb.93.10.1501 Peltola H, Kellomäki S, Hassinen A, Granander M (2000). Mechanical stability of Scots pine, Norway spruce and birch: an analysis of tree-pulling experiments in Finland. Forest Ecology and Management 135 (1-3): 143-153. - doi: 10.1016/ S0378-1127(00)00306-6

Peters A, Hothorn T (2009). Ipred: improved predictors. Web repository, pp. 11. [online] URL: http://cran.r-project.org/web/packages/ipred/vign ettes/ipred-examples.pdf

Petty JA, Swain C (1985). Factors influencing stem breakage of conifers in high winds. Forestry 58 (1): 75-84. - doi: 10.1093/forestry/58.1.75 Piermattei A, Renzaglia F, Urbinati C (2012). Recent expansion of Pinus nigra Arn. above the timberline in the central Apennines, Italy. Annals 
of Forest Science 69 (4): 509-517. - doi: 10.1007/s13595-012-0207-2

Pretzsch H (2010). Forest dynamics, growth and yield. Springer, Berlin, Heidelberg, Germany, pp. 664. - doi: 10.1007/978-3-540-88307-4

Quine CP (1995). Assessing the risk of wind damage to forests: practice and pitfalls. In: "Wind and Trees" (Coutts MP ed). Cambridge University Press, Cambridge, UK, pp. 379-403. - doi: 10.1017/CBO9780511600425

Quine CP (2000). Estimation of mean wind climate and probability of strong winds for wind risk assessment. Forestry 73 (3): 247-258. - doi 10.1093/forestry/73.3.247

R Core Team (2013). R: a language and environment for statistical computing. R Foundation for Statistical Computing, Vienna, Austria. [online] URL: http://www.r-project.org

Shapiro SS, Wilk MB (1965). An analysis of variance test for normality (complete samples). Biometrika 52 (3-4): 591-611. [online] URL: http://www.jstor.org/stable/2333709

Slodicak M, Novak J (2006). Silvicultural measures to increase the mechanical stability of pure secondary Norway spruce stands before conver- sion. Forest Ecology and Management 224 (3): 252-257. - doi: 10.1016/j.foreco.2005.12.037

Spearman C (1904). The proof and measurement of association between two things. The American journal of psychology 100 (3-4): 441-71. URL. [online] URL: http://www.ncbi.nlm.nih.gov/pub $\operatorname{med} / 3322052$

Talkkari A, Peltola H, Kellomäki S, Strandman H (2000). Integration of component models from the tree, stand and regional levels to assess the risk of wind damage at forest margins. Forest Ecology and Management 135 (1-3): 303-313. doi: 10.1016/S0378-1127(00)00288-7

Thomasius H, Eutter D, Marsch M (1986). Massnahmen zur Stabilisierung von Fichtenforsten gegenüber Schnee-und Sturmschàden [Measures to stabilize Norway spruce plantations towards wind and snow damages]. In: Proceedings of the " $18^{\text {th }}$ IUFRO Conference". Ljubljana (Slovenia) 7-21 September 1986. Jugoslavenska Akademija Znanosti i Umjetnosti, Zagreb, Croatia, pp. 103. [in German]

Valinger E, Lundqvist L, Bondesson L (1993). Assessing the risk of snow and wind damage from tree physical characteristics. Forestry 66
(3): 249-260. - doi: 10.1093/forestry/66.3.249 Vanninen P, Ylitalo H, Sievänen R, Mäkelä A (1996). Effects of age and site quality on the distribution of biomass in Scots pine (Pinus sylvestris L.). Trees 10 (4): 231-238. - doi: 10.1007/ BF02185674

Von Gadow K, Bredenkamp B (1992). Forest management. Academica, Pretoria, South Africa, pp. 151.

Wang Y, Titus SJ, LeMay VM (1998). Relationships between tree slenderness coefficients and tree or stand characteristics for major species in boreal mixedwood forests. Canadian Journal of Forest Research 28 (8): 1171-1183. - doi: 10.1139/x98-092

Wilson JS, Oliver CD (2000). Stability and density management in Douglas-fir plantations. $\mathrm{Ca}$ nadian Journal of Forest Research 30 (6): 910920. - doi: 10.1139/x00-027

Zeng H, Garcia-Gonzalo J, Peltola H, Kellomäki S (2010). The effects of forest structure on the risk of wind damage at a landscape level in a boreal forest ecosystem. Annals of Forest Science 67 (1): 111-111. - doi: 10.1051/forest/2009090 